\title{
Enhancing EFL Students' Speaking Competency Through Animated Learning Video
}

\author{
Luh Gede Eka Wahyuni ${ }^{1, *}$ Ni Putu Astiti Pratiwi ${ }^{1}$ \\ ${ }^{1}$ English Language Education Study Program, Universitas Pendidikan Ganesha, Singaraja, Indonesia \\ ${ }^{*}$ Corresponding author.Email: ekawahyuni@undiksha.ac.id
}

\begin{abstract}
Communicative competence seems to be a major issue to achieve by primary students in learning English in online learning process during COVID-19 outbreak. This is due to the lack of English exposure and innovative learning media which relate to $21^{\text {st }}$ century learning. For this reason, this sequential explanatory mixed-method study was conducted to investigate the effectiveness of animated learning video upon students' speaking competency and to describe their responses. Divided into two groups, 70 upper-class students in suburban primary schools participated as the subject. Test, questionnaire, and interview were used to collect the data. The data of the test were analyzed by using a t-test formula to investigate whether there was a significant difference in students' speaking competency between the two groups. The data of the questionnaire and interview were analyzed descriptively to see students' responses towards the effectiveness of animated learning video. The statistical analysis showed that tobs value of Sig. (2 tailed) was .011 which means that there is a significant difference in students' speaking competency. The animated learning videos help them pronounce the words properly, improve their vocabulary mastery, be familiar with the structure, and be gradually more fluent in speaking. In short, animated learning video is appropriate to enhance students' speaking.
\end{abstract}

Keywords: English Learning, Speaking Competency, Animated Learning Video.

\section{INTRODUCTION}

Being competent in speaking is the most important thing to do when the EFL students are involved in a interactive process for constructing and receiving information [1] to communicate with people in society. The communication competence helps them express their minds, ideas, thought, and intention to other students easily [2]. This is the mastery of communication to help students in a conversation and make a new friend as well as having proper information delivery [3]. The competence includes how to manage the ideas in conveying sentences by paying attention to correct and good pronunciation, vocabulary, grammar, and spelling. Using appropriate grammatical structure and dictions as well as apply proper courteous and manner attitude to the communication context, the students should speak competently and fluently to be good communicators.

However, the expectation of having the students competent in their speaking cannot be fully achieved due to several problems. The current situation where the remote teaching and learning process are still carried out has the biggest impact on the students' communication development in English, especially those who live in suburban areas where English subject has been omitted from the curriculum in most of the schools. Being required to master vocabulary, grammar and structure, as well as pronunciation to be fluent speakers is the biggest challenge they have [3]. A further explanation also shows that some students with insufficiency of the vocabulary knowledge and less confidence feel difficult to produce the words [4]. Such things decrease students' opportunity to practice the dialogue or monologue in English [1]. Those matters are the barrier for the students to convey or respond to the information.

As the students are enforced to learn at home without appropriate curriculum and guidance from the experienced English teachers, the exposure of English language learning environment becomes the major factor. The young learners have more opportunity to use their mother tongue more than the target language. The interference of their mother language in learning the target one could probably decrease the language exposure they should have in learning [5] and may 
prevent their speaking ability [6]. Thus, the English teachers need to find an appropriate solution to extend the speaking practice out of class to expose the target language more in online learning context [7].

Considering the global shift in teaching-learning process towards online learning and related regulation of its implementation, the utilization of technology which has a reflection on the innovative learning takes an important role in supporting students' learning [8]. It is likely a kind of learning management which helps the teachers create better learning experience [9] and the students learn autonomously [10]. Animated learning media in the form of video might be very interesting for the students, especially young learners. In online learning process, animated learning video as technology-based learning media gives the best sight for everyone that it is a necessity to make use of it into learning process [11]. It means both teachers and students need to take the advantages of developing technology to support the teaching and learning process in this era. Teachers can provide various learning media and students can learn best from it.

Regarding to the utilization of technology in learning process, several studies have discussed about the effectiveness of learning video $[11][12][6][13][14][4][1][7][15]$, the perspective of its implementation [16][17], and its role in online learning process [18].

However, those studies mostly concern on teaching speaking for adult learners through video blog, YouTube, authentic video, digital recording, and films both in ESL and EFL classroom context based on certain curriculum. Their implementation also emphasizes on speaking skills such as pronunciation and fluency, speaking anxiety, oral performance, and prosodic competence. Less studies are found to implement animated learning video in the suburban areas where English has been omitted from the curriculum in primary schools. Thus, this current study is urged to do to prove its significance towards suburban primary students who have lost their English learning exposure. A mixed-method study in the form of sequential explanatory design involving 70 students was applied to investigate whether there is significant different on students' speaking competency through the implementation of animated learning video. This study also discusses the students' responses towards the implementation of animated learning video descriptively.

\section{METHOD}

This was a mixed method with sequential explanatory mixed method design. It uses two phases of combination method [19] which helps this study to quantitatively investigate the effectiveness of animated learning video in enhancing students' speaking competency as well as to qualitatively describe their response of its implementation through questionnaire and interview guide (see Figure 1).

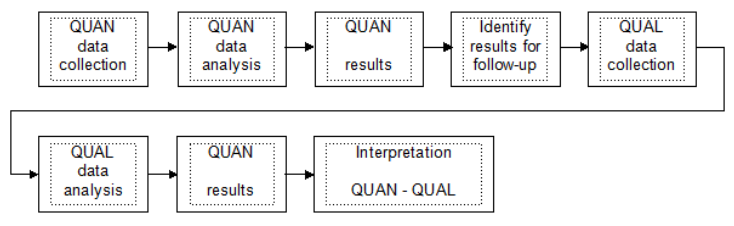

Figure 1 Sequential Explanatory Mixed Method Design pattern

Post-test only control group design was administered to obtain quantitative data. 70 upper-class students who lived in suburban area of Pancasari Village were taken as the research subject. They were divided into two group in which only experimental group was treated by the animated learning video. Speaking test and speaking rubric were the instrument used to investigate whether there was any significant difference in students' speaking competency. The hypothesis was tested by using two tailed independent sample t-test. The result of this data was then completed with analysis of effect size to know the strength of the effectiveness of animated video upon students' speaking competency. Cohen's d was used to investigate the effect size (see Table 1).

Table 1. Effect Size Interpretation

\begin{tabular}{|l|l|}
\hline Value & Effect Size Interpretation \\
\hline 0.20 & Small \\
\hline 0.50 & Medium \\
\hline 0.80 & Large \\
\hline
\end{tabular}

To strengthen the findings of the effectiveness of animated learning video, the questionnaire and interview guide were administered to obtain the data of the students' responses toward its implementation in enhancing students' speaking competency. The questionnaire contained 10 statements which were constructed based on the theory of the advantages of animated learning video [20] and speaking competency [21]. The interview guide was conducted to deepen the analysis of the questionnaire. Both the data gathered from the questionnaire and interview were descriptively interpreted to support the findings of quantitative analysis.

\section{RESULT AND DISCUSSION}

The scores gathered from the speaking test were analyzed quantitatively to test the hypothesis. Descriptive analysis was conducted formerly to see the description of each data. The result of the analysis can be seen in Table 2 . 
Table 2. Result of descriptive analysis interpretation of each group

\begin{tabular}{|c|c|c|c|c|c|}
\hline \multicolumn{6}{|c|}{ Descriptive } \\
\hline & \multicolumn{3}{|l|}{ Group } & Statistic & Std. Error \\
\hline \multirow[t]{26}{*}{ Speaking_Score } & \multirow[t]{13}{*}{ Experiment } & \multicolumn{2}{|l|}{ Mean } & 77.6000 & 1.46396 \\
\hline & & \multirow[t]{2}{*}{ 95\% Confidence Interval for Mean } & Lower Bound & 74.6249 & \\
\hline & & & Upper Bound & 80.5751 & \\
\hline & & \multicolumn{2}{|l|}{ 5\% Trimmed Mean } & 77.7143 & \\
\hline & & \multicolumn{2}{|l|}{ Median } & 76.0000 & \\
\hline & & \multicolumn{2}{|l|}{ Variance } & 75.012 & \\
\hline & & \multicolumn{2}{|l|}{ Std. Deviation } & 8.66093 & \\
\hline & & \multicolumn{2}{|l|}{ Minimum } & 60.00 & \\
\hline & & \multicolumn{2}{|l|}{ Maximum } & 94.00 & \\
\hline & & \multicolumn{2}{|l|}{ Range } & 34.00 & \\
\hline & & \multicolumn{2}{|l|}{ Interquartile Range } & 14.00 & \\
\hline & & \multicolumn{2}{|l|}{ Skewness } & -.144 & .398 \\
\hline & & \multicolumn{2}{|l|}{ Kurtosis } & -.548 & .778 \\
\hline & \multirow[t]{13}{*}{ Control } & \multicolumn{2}{|l|}{ Mean } & 72.4571 & 1.32230 \\
\hline & & \multirow{2}{*}{$95 \%$ Confidence Interval for Mean } & Lower Bound & 69.7699 & \\
\hline & & & Upper Bound & 75.1444 & \\
\hline & & \multicolumn{2}{|l|}{$5 \%$ Trimmed Mean } & 72.3968 & \\
\hline & & \multicolumn{2}{|l|}{ Median } & 72.0000 & \\
\hline & & \multicolumn{2}{|l|}{ Variance } & 61.197 & \\
\hline & & \multicolumn{2}{|l|}{ Std. Deviation } & 7.82283 & \\
\hline & & \multicolumn{2}{|l|}{ Minimum } & 60.00 & \\
\hline & & \multicolumn{2}{|l|}{ Maximum } & 86.00 & \\
\hline & & \multicolumn{2}{|l|}{ Range } & 26.00 & \\
\hline & & \multicolumn{2}{|l|}{ Interquartile Range } & 10.00 & \\
\hline & & \multicolumn{2}{|l|}{ Skewness } & .137 & .398 \\
\hline & & \multicolumn{2}{|l|}{ Kurtosis } & -.931 & .778 \\
\hline
\end{tabular}

The mean scores presented in the table show that the experimental group students have higher mean score (77.60) than the control group (72.45). It indicates that students in experimental group possess better performance in speaking competency compared to control group students.
The inferential analysis was conducted later, including normality and homogeneity data test, as preliminary data analysis before testing the hypothesis. The result of preliminary data analysis is shown in Table 3.

Table 3. Result of normality and homogeneity data distribution

\begin{tabular}{|c|c|c|c|c|c|c|c|c|}
\hline \multicolumn{9}{|c|}{ Tests of Normality } \\
\hline & \multirow{2}{*}{\multicolumn{2}{|c|}{ Group }} & \multicolumn{3}{|c|}{ Kolmogorov-Smirnov ${ }^{a}$} & \multicolumn{3}{|c|}{ Shapiro-Wilk } \\
\hline & & & $\begin{array}{l}\text { Statisti } \\
\text { C }\end{array}$ & df & Sig. & $\begin{array}{l}\text { Statisti } \\
\mathrm{C}\end{array}$ & df & Sig. \\
\hline \multirow[t]{2}{*}{ Speaking_Score } & \multicolumn{2}{|l|}{ Experiment } & .120 & 35 & $.200^{*}$ & .968 & 35 & .395 \\
\hline & \multicolumn{2}{|l|}{ Control } & .109 & 35 & $.200^{*}$ & .953 & 35 & .141 \\
\hline \multicolumn{9}{|c|}{ *. This is a lower bound of the true significance. } \\
\hline \multicolumn{9}{|c|}{\begin{tabular}{|l|l} 
a. Lilliefors Significance Correction \\
\end{tabular}} \\
\hline \multicolumn{9}{|l|}{ Speaking_Score } \\
\hline \multirow{2}{*}{\multicolumn{2}{|c|}{$\begin{array}{l}\text { Levene Statistic } \\
.251\end{array}$}} & \multirow{2}{*}{\multicolumn{2}{|c|}{$\begin{array}{ll}\mathrm{df1} \\
1\end{array}$}} & \multirow{2}{*}{\multicolumn{2}{|c|}{ df2 }} & \multicolumn{3}{|l|}{ Sig. } \\
\hline & & & & & & .618 & & \\
\hline
\end{tabular}

The Kolmogorov-Smirnov value presented in the table shows that the data were normally distributed ( 0.200 for both experimental and control group at the significant level of 0.05 . The result of Levane Statistics shows that the data were categorized homogeneously with the value of $\mathrm{F}=0.251$ at significant level of 0.618 .
As the data were clarified normally and homogeneously, hypothesis testing using t-tes analysis was conducted to see whether there was any significant difference in students' speaking competency. The result of t-test is presented in Table 4. 
Table 4. Result of t-test analysis

\begin{tabular}{|c|c|c|c|c|c|c|c|c|}
\hline \multicolumn{2}{|c|}{$\begin{array}{l}\text { Levene's Test for } \\
\text { Equality of Variances }\end{array}$} & \multicolumn{7}{|c|}{ t-test for Equality of Means } \\
\hline \multirow[b]{2}{*}{$\mathrm{F}$} & \multirow[b]{2}{*}{ Siq. } & \multirow[b]{2}{*}{$\mathrm{t}$} & \multirow[b]{2}{*}{ Df } & \multirow{2}{*}{$\begin{array}{l}\text { Sig. (2- } \\
\text { tailed) }\end{array}$} & \multirow{2}{*}{$\begin{array}{l}\text { Mean } \\
\text { Difference }\end{array}$} & \multirow{2}{*}{$\begin{array}{l}\text { Std. Error } \\
\text { Difference }\end{array}$} & \multicolumn{2}{|c|}{$\begin{array}{l}95 \% \text { Confidence Interval of } \\
\text { the Difference }\end{array}$} \\
\hline & & & & & & & Lower & Upper \\
\hline .251 & .618 & 2.607 & 68 & .011 & 5.14286 & 1.97273 & 1.20633 & 9.07938 \\
\hline
\end{tabular}

A significant difference is confirmed when the value of Sig. (2-tailed) is lower than 0.05 [22]. According to Table 4, the value of Sig. (2-tailed) indicates that the null hypothesis is accepted; that there is a significant difference in students' speaking competency between students who were taught by animated learning video and those who were taught conventionally. It can be seen from better achievement of experimental group students in pronunciation, fluency, and vocabulary.

Based on the result of questionnaire, the experimental group students admitted that they made less mistakes in pronouncing the words after the treatment. As they learn English as a foreign language, the use of animated learning video gives a big impact for students. The animated learning video such as films, cartoons, video, or audio-visual based can be a very authentic model or real example [23] to improve students' ability in pronouncing the words appropriately as they imitate how the characters say the words [1]. By imitating the video, the students can get the correct way of saying the words, especially in reading the words that are sometimes similar in their mother tongue [23]. In other words, the media can be used as a good source for the students to check or confirm their incorrect pronunciation [1].

The data revealed that animated learning video gives minor impact to students' fluency during the performance. Although their pronunciation may be influenced the most, the students still did more mistakes in showing their fluency; however, it is a good source to help them improve their mastery of intonation, word stress, and pauses [15]. Since it presents the real language used in communication, new words, phrases, and expressions, the video enhances the students to speak more and challenges them to perform their understanding on certain topic discussion [24]. The real target language presented in the video can be a good exposure for students to develop their ability to speak and use the language in a real-life conversation [25]. During the treatment, it was also found that students needed more time to be more fluent in speaking as they need more practice. As they are able to enhance their pronunciation and vocabulary, they will be able to speak fluently in their communication. It can be said that vocabulary mastery is also an important aspect in improving the fluency.
After the treatment, the students seemed to use more varied vocabulary mostly in their performance. Based on the result of questionnaire, it was found that animated learning video is an interesting tool to introduce and deepen students' vocabulary mastery. It is a great and interesting media to increase students' knowledge of English vocabulary [26]. The video enables students to learn the words correctly especially memorize the names of the objects. It creates an opportunity for students to employ vocabulary in different contextual situations, for it provides needed stimulus for building up and using the language in different forms [27]. The video helps students in constructing their knowledge through an interactive learning situation which enables to stimulate their activeness and enhance their skills to discover the knowledge [27]. Once they are able to construct the knowledge and build up their understanding, they will be able to sharpen their ability in using the language [28] and be more creative in performance [10]. However, this improvement was also strengthened by the feedback. Based on the interview, it was greatly understood that the improvement of students' vocabulary knowledge was influenced by the reinforcement in form of reward. Feedback allows the students to have direct discussion which is believed to help students to learn more [29].

The improvement of students' speaking competency through the use of animated learning video is in the interfere of students' motivation to learn. It could be seen from the positive attitude shown by students. Based on the result of interview, students argued that the videos were very interesting; that they felt so easy to understand the material because they were enthusiastic during the learning process. The video that contains audio visual will show a very significant role to motivate the students in learning process as well as make the atmosphere of students' learning more interesting [1][30]. The interactive activities contained in the video could make the students excited enough to take participation, for instance, answering single question or quiz in the video [31]. It shows that animated learning video is suitable to use in enhancing students' speaking as it interests students [32] and provides them beneficial and engaging activities [33][34]. 
Although the result of this study shows a significant difference in students' speaking competency, it did not give a big effect for the students as the difference of the groups' mean scores was not that much. It can be seen from the result of the effect size of the data as presented in Table 5.

Table 5. Result of effect size analysis

\begin{tabular}{|l|l|l|l|l|l|}
\hline Group & Mean & Standard Deviation & N & Cohen d & Remarks \\
\hline Experiment & 77.60 & 8.660 & 35 & 0.624 & $\begin{array}{l}\text { Medium Effect } \\
\text { Size }\end{array}$ \\
\hline Control & 72.45 & 7.822 & & & \\
\hline
\end{tabular}

The value of Cohen-d which is only 0.624 shows that the use of animated learning video only gives moderate effect on students' speaking competency. It means that there are other factors that affect students' performance.

According to the result of interview with students, some other factors were identified to interfere to their performance during the treatment. The most affected factor observed during the performance was students' psychological condition such as anxiety. These factors could mentally and spiritually influence students' acquisition, especially in recalling out the language used in communicating the ideas [35]. Specifically, students who have high level of anxiety could lead themselves into subject discouragement and failure [36]. Anxiety appears from the classroom learning condition with the difference of language ability level [37]. Students who are good in their English proficiency will be more confident compared to those with low proficiency. They will tend to dominate the class more which make the low students worry and less active during the lesson. A feeling of being worry may lead the students prefer to be silent rather than get criticized in front of a number of people that make them shy of making the mistakes [21].

The students' success in performing their speaking ability is also much influenced by their attitude toward the language. Attitude develops as a result of getting the direct or vicarious experiences which are mostly affected by the environment such as parents, teachers, peers, and one-self [1]. This will relate to how both the environment and the students could motivate themselves in learning. Students with high motivation will be able to learn the language faster and be more sensitive in using the language and it results on positive view toward the language. If students have unfriendly attitude toward the language learning, no substantial improvement will be possessed in acquiring the language [38]. Although students have good communicative competence, without having positive attitude towards the performance, no learning goals can be achieved well.

\section{CONCLUSION}

This study discusses the significant difference in students' speaking competency between the students who were taught by using animated learning video and those who were taught conventionally, that is confirmed by higher achievement shown by experimental group $(\mathrm{M}=77.60)$ compared to control group $(\mathrm{M}=72.45)$ as well as by the result of t-tes (Sig.2-tailed $=0.011$ ).

The findings of the study imply that the animated learning video generally can be used as a learning media to teach English, especially to train and enhance students' speaking skill. If the video can be utilized maximally, both teachers and students will get better impacts on their professional development and English achievement. However, some factors seem to interfere the students' learning progress, resulting on the moderate rate of the students' communication development, which need to be studied later.

As this shows a significant result, teachers are suggested to implement animated learning video as a kind of digital learning media in teaching speaking. Although this study gives significant result with moderate effect, students' psychological condition that affects their speaking skill need to be taken into consideration. To put students in a conducive learning situation, teachers need to create more innovative learning activities that can activate all students to participate. It is also suggested for other researchers to investigate some effectives learning activities for encouraging students in learning.

\section{AUTHORS' CONTRIBUTIONS}

In the accomplishment of this work, the authors have different roles. The first author mainly contributed in preparing the instrument, collecting the data, analyzing and interpreting the data, and writing the study result. The second and third author helped in collecting the data, reviewing and revising the data interpretation, and reviewing the content of the paper. Although they have different job description, they work together and support each other. 


\section{ACKNOWLEDGMENTS}

This is a small work that was conducted in a suburban area in the northern part of Bali, especially in Pancasari village. The study was conducted due to a fact that most of the primary schools have not taught English subject anymore, while they need to get the English exposure earlier as the areas has a potential to develop their tourism.

During the study, several parties have participated to help. A big thank is delivered to the research grants from our institution for its support of the study funding and the headman who has given his permission. A very great appreciation is given for the students in the village who have fully participated as the subject.

\section{REFERENCES}

[1] S. Rasyid, Using cartoon movie to improve speaking skill, Research in English and Education (READ), vol. 1(2), pp. 161-168, 2016.

[2] G. M. S. Mohammed, Speaking skills in online learning: An investigation of the strategies used by ESL learners at the University of Bisha, Asian EFL Journal Research Articles, vol. 28 (2.3), pp. 120135, 2021.

[3] H. Puspitasari, E. Bunau, and D. Novita, The use of cartoon movie in improving students speaking ability in using expression of asking for and giving help, Jurnal Pendidikan dan Pembelajaran Khatulistiwa, vol. 3(8), pp. 1-9, 2013.

[4] R. Amini and A. F. R. Syafei, Teaching speaking fluency to junior high school students through animation movie. Journal of English Language Teaching, vol. 6(1), pp 1-8, 2017.

[5] N. H. Tuan and T. N. Mai, Factors affecting students' speaking performance at LE Thanh Hien High School, Asian Journal of Educational Research, vol. 3(2), pp. 8-23, 2015.

[6] N. A. Madzlan, G. H. Seng, H. V. Kesevan, Use of video blogs in alleviating public speaking anxiety among ESL learners, Journal of Education and ELearning Research, vol. 7(1), pp. 93-99, 2020.

[7] N. Göktürk, Examining the effectiveness of digital video recordings on oral performance of $\mathrm{EFL}$ learners, Teaching English with Technology, vol. 16(2), pp. 71-96, 2016. DOI: http://www.tewtjournal.org

[8] V. Puncreobutr, Education 4.0: New challenge of learning, St. Theresa Journal of Humanities and Social Science, vol. 2(2), pp. 92-97, 2018. http://www.stic.ac.th/ojs/
[9] C. W. Anggraeni, Promoting education 4. 0 in English for survival class: What are the Challenges?, Metathesis: Journal of English Language Literature, and Teaching, vol. 2(1), pp. 12-24, 2018.2 DOI: https://doi.org/10.31002/metathesis.v1i2.676

[10] Z. Wang, An analysis on the use of video Materials in College English Teaching in China, International Journal of English Language Teaching, vol. 2(1), pp. 23-28, 2015.

[11] H. A, Saed, A.S. Haider, S. Al-Salman, and R. F. Hussein, The use of Youtube in developing the speaking skills of Jordanian EFL university students, Hellion, Vol. 7, pp. 1-6, 2021.

[12] A. N. Syafiq, A. Rahmawati, A. Anwari, and T. Oktaviana, Increasing speaking skill through Youtube video as English learning material during online learning in pandemic COVID-19, Elsya: Journal of English Language, vol. 3(1), pp. 50-55, 2021.

[13] C. Yükselir and S. Kömür, Using online videos to improve speaking abilities of EFL learners, European Journal of Education Studies, vol. 3(5), pp. 255-266, 2017 [Presented in the 9th ELT Research Conference, 12-14 May 2016, Çanakkale, Turkey].

[14] I. M. B. Al-Domi, The effect of using authentic videos on training center and community service students' prosodic competence and motivation, Arab World English Journal, vol. 8 (4), pp. 85-100, 2017.

DOI:

https://dx.doi.org/10.24093/awej/vol8no4.6

[15] S. Ruey and Y. Kun, Using films to teach speaking in the esl classroom: A case study, UNISEL Journal of Social Sciences and Humanities, vol. 1 (1), pp. 50-56, 2014.

[16] A. K. R. Nasution, Youtube as a media in English Language Teaching (ELT) context: Teaching procedure text. Utamax: J. Ultimate Res. TrendsEduc., 1(1), pp. 29-33, 2019.

[17] O. Akbari and A. Rasavi, Using authentic materials in the foreign language classrooms: Teachers' perspectives in EFL classes, Int. J. Res. Stud. Educ. 5(2), pp. 105-116, 2016.

[18] L. Bajram and M. Ismaili, The role of video materials in EFL classroom, Procedia-Social and Behavioral Science, Vol. 232, pp. 502-506, 2016 [International Conference on Teaching and Learning English as an Additional Language, GlobELT 2016, 14-17 April 2016, Antalya, Turkey] 
[19] J. W. Creswell, Educational Research: Planning, Conducting, and Evaluating Quantitative and Qualitative Research, Third Education, United States of America: Pearson Education, Inc., 2008.

[20] J. G. E. Brewster and G. Denis, The Primary English Teacher's Guide, London: Penguin English Guides, 2002.

[21] H. D. Brown, Language Assessment: Principles and Classroom Practices, San Francisco State University, 2004.

[22] N. Dantes, Metodologi Penelitian: Seri Analisis Varians dan Validasi Instrumen, Singaraja: Program Pascasarjana Universitas Pendidikan Ganesha, 2011.

[23] Y. Dharmawan and M. Saniyati, Improving students' pronunciation by using audio-visualassisted text. The Fourth International Conference on Education and Language (4th ICEL). pp 75-80, 2016.

[24] R. Madiyoh, N. Hidayanto, and P. Setyo, The effectiveness of authentic short movies in enhancing students speaking skill, International Journal of English Literature and Culture, vol. 6(3), pp. 44-49, 2018.

[25] N. M. Hayati, The eEffectiveness of using cartoon videos in teaching speaking to the students of SMP N 2 Rantau Kalimantan Selatan in academic year of 2013/2014, Journal of English Language Teaching and Applied Linguistics, vol. 1(2), pp. 57 $-73,2018$.

[26] F. Ulfa, A. Salim, and D. Permana, Teaching vocabulary using cartoon movie at SDN Bunklotok Batujai Lombok Tengah, Journal of Language and Language Teaching, vol. 5(1) : 23-27, 2017.

[27] N. Abuzahra, M. Farrah, and S. Zalloum, Using cartoon in language classroom from a constructivist point of view, Arab World English Journal (AWEJ), vol. 3, pp. 229-245, 2016.

[28] R. Parvin and S. Salam, The effectiveness of using technology in english language classrooms in government primary schools in Bangladesh, Forum for International Research in Education, vol. 2(01), pp. 47-59, 2015.

[29] A. Alzamil, "Teaching English speaking online versus face-to-face: Saudi students' experience during the COVID-19 pandemic", Aarab World English Journal, Vol. 12 (1), pp. 19-27, 2021. doi: https://dx.doi.org/10.24093/awej/vol12no1.2
[30] C. Wilson, Role of video in the F/SL classroom, Abu Dhabi The Internet TESL Journal, vol. 6(1), pp. 20-29, 2000.

[31] L. G. E. Wahyuni and A. A. S. Tantri, English learning media for EFL elementary learners, Advance in Social Science, Education, and Humanities Research, vol. 394, 2020 [Presented on 3rd International Conference on Innovative Research Across Disciplines 2019].

[32] J. A. Akerele and A. F. Afolabi, Effect of video on the teaching of library studies among undergraduates in Adeyemi College of Education Ondo, Library Philosophy and Practice (e-journal), vol. 1, no. 7, 2012.

[33] S. Bauk and R. Radlinger, Teaching ECDIS by Camtasia Studio: Making the content more engaging, International Journal on Marine Navigation, and Safety of Sea Transportation, vol. 7(3), pp. 375-380, 2013.

[34] W. Muhanna, Using Camtasia videos in assigned projects for middle east university students and their attitudes towards it, International Journal of Humanities and Social Science, vol. 8(11), pp. 7582, $2018 . \quad$ DOI: https://doi.org/10.30845/ijhss.v8n11p

[35] L. Budianto, Students' psychological factors in SLA: A dillema for teachers of English, Journal of Lingua, vol. 5(1), pp. 62-67, 2010.

[36] L. M. Leong and S. M. Ahmadi, An analysis of factors influencing learners' english speaking skills, International Journal of Research in English Education, vol. 2 (1), pp. 34-41, 2017.

[37] M. Bashir, M. Azeem, and A. H. Dogar, Factor affecting students' English speaking skills, British Journal of Arts and Social Sciences, vol. 2(1), pp. 34-50, 2011.

[38] T. Merisuo-Storm, Pupil's attitudes towards foreign-language learning and the development of literacy skills in bilingual education, Teaching and Teacher Education, vol. 23, pp. 226-235, 2017. 